whatever movement of shore-line there was, seems to have been westward with increase of land.

Two other points I briefly touch. Prof. Hull thinks that I do not recognize sufficiently, if at all, his most important point, viz. " the increase of thickness of sediments to the N.E. and E., and their attenuation and replacement by limestone in the opposite direction." If I did not lay stress on this, it was only because I supposed it generally recognized, although Prof. Hull brings it out in a very striking way in his figures. No one has emphasized these facts, and their significance as showing a large land-mass to the north-east and a wide ocean to the south-west, more than I have.'

Again, in my previous communication" I said, "There is no reason why the eastern land-mass, which sufficed to contribute $30,000 \mathrm{ft}$. of Silurian and Devonian sediments, should not have been sufficient to contribute the much smaller amount of Carboniferous sediments." Prof. Hull thinks this a begging of the question at issue. For, says he, "the narrow strip of land allowed by Prof. Le Conte was quite insufficient to produce $30,000 \mathrm{ft}$. of conformable sediments." I can only say in reply that Prof. Hull's map of Silurian times led me astray: for this shows just such a land-mass as I suppose, while his map of Carboniferous times shows a very much greater land-mass. I suppose, now, however, that he imagines this land-mass to have increased on its eastern side through Silurian and Devonian times. If so, it must have increased very rapidly, for the Silurian alone is 20,000 ft. thick in the Appalachian region. Joseph IJE Conte.

\title{
PERMANENCE OF CONTINENTS \& OCEAN-BASINS, WITH SPECIAL REFERENCE TO THE FORMATION AND DEVELOPMENT OF THE NORTH AMERICAN CONTINENT. ${ }^{3}$
}

Sir,-Will you allow me to make a correction? Prof. Chamberlin has kindly drawn my attention to the fact that in my original communication to you on this subject ${ }^{3} \mathrm{I}$ have misrepresented him, and I wish therefore to acknowledge my error. The map on $p .62$ of Prof. Chamberlin's work on the Geology of Winconsin was not intended, as I supposed, as a map of Archæan areas, but really as a map of land during a portion of Archæan times, viz. (if I understand him) at the beginning of the period of Huronian sedimentation. I was misled by its great resemblance to the usually recognized map of Archæan areas. The confusion of thought to which I referred does indeed exist, but Prof. Chamberlin is not an example of it.

Let us hope that Prof. Chamberlin will give us more fully his mature views on this so olscure and yet so important subject. No one is more competent than he to write with authority on the subject.

Joseph Le Conte.

Berkeley, California, May 3, 1886.

1 Am. Jour, vol. iv. p. 463, 1872. Elements of Geol. p. 289.

2 See Geol. Mag. Miarch, 1886, p. 100.

3 Geol. Mag. 1S86, Dec. III. Vol. III. p. 97. 